\title{
Detection of ALK protein expression in lung squamous cell carcinomas by immunohistochemistry
}

\author{
Jiandong Wang ${ }^{1 *}$, Qin Shen ${ }^{1}$, Qunli Shi ${ }^{1}$, Bo Yu ${ }^{1}$, Xuan Wang ${ }^{1}$, Kai Cheng ${ }^{1}$, Guangming Lu² and Xiaojun Zhou ${ }^{1 *}$
}

\begin{abstract}
Background: The echinoderm microtubule-associated protein-like 4 (EML4) gene and the anaplastic lymphoma kinase (ALK) gene rearrangements occur in approximately $5 \%$ of lung adenocarcimomas (ACA), leading to ALK overexpression and predicting response to targeted therapy. To the present, few studies have been focused on the expression of ALK protein in lung squamous cell carcinomas (SqCC). Only several cases of lung SqCC were reported expression of ALK protein. No clinical study has been published to explicit the relationship between ALK expression and the response to targeted therapy in SqCC.

Methods: In this study, we analyzed ALK protein expression with a specific rabbit monoclonal Ig antibody (D5F3 clone) in 207 cases of lung SqCC. The positive cases were confirmed with ALK fluorescence in situ hybridization (FISH) and RT-PCR.

Results: We found that 3 out of 207 (1.4\%) cases of lung SqCC were ALK positive detected by IHC staining, which were confirmed by ALK FISH and RT-PCR.

Conclusions: Our results indicate that ALK protein expression is not a rare molecular event in SqCC. Although the frequency of EML4-ALK rearrangements is lower in lung SqCC than that in lung adenocarcinomas, their presence may provide additional treatment options in lung SqCC. The response of SqCC patients with ALK expression to target therapy of crizotinib should be explored.
\end{abstract}

Keywords: Anaplastic lymphoma kinase, Lung squamous cell carcinoma, IHC, D5F3 clone

\section{Background}

Despite the extensive research and clinical efforts dedicated to the management of lung cancer in the past decade, lung cancer remains the leading cause of cancerrelated mortality in China and Western countries [1-4]. Patients with lung cancer account for approximately 1.4 million deaths per year worldwide and approximately 160,000 deaths per year in the United States [5]. Histologically, lung cancer is dichotomized into small cell lung carcinoma and non-small cell lung carcinoma (NSCLC). NSCLCs represent a diverse entity that can be subclassified further into distinct histologic subtypes including adenocarcinoma, squamous cell carcinoma

\footnotetext{
*Correspondence: jd_wang@outlook.com; nanjing_81@yahoo.com 'Department of Pathology, Jinling Hospital, Nanjing University School of Medicine, Nanjing 210002, China

Full list of author information is available at the end of the article
}

(SqCC), large cell carcinoma, large cell neuroendocrine carcinoma, anaplastic carcinoma, and giant cell carcinoma. NSCLCs represent approximately $80 \%$ of all lung cancer subtypes and it is the leading worldwide cause of cancer related death. Lung SqCC is a common type of NSCLCs, causing approximately 400,000 deaths per year worldwide. Most lung cancers are often diagnosed at advanced stages of the disease, and the mainstay of therapy is systemic chemotherapy, typically with a platinum-based regimen. Given that conventional chemotherapeutic regimens only marginally improve the outcome of such individuals, their median survival time is less than one year after diagnosis. A plateau has been reached in the efficacy of chemotherapy using nonspecific cytotoxic agents. Recent progress in understanding the biology of this tumor, characterization of NSCLC by molecular typing, particularly in adenocarcinomas of the 
lung, has led to the investigation of therapeutic agents that target dominant oncogenic mutations and show improved response rates in patients with NSCLCs [6-11]. In the recent years, several potential oncogenic drivers have been identified in patients with NSCLC, including epidermal growth factor receptor (EGFR), B-Raf (BRAF), Kirsten rat sarcoma 2 viral oncogene homolog (KRAS), mesenchymal epithelial transition factor (MET), human epidermal growth factor receptor 2 (HER2), and andanaplastic lymphoma kinase gene (ALK). Specifically, the discovery of the biologic and therapeutic importance of acquired genetic alterations in 2 genes that encode pharmacologically targetable tyrosine kinases involved in growth factor receptor signaling, epidermal growth factor receptor (EGFR) and anaplastic lymphoma kinase (ALK), has changed the way these cancers are diagnosed and treated. It is well known that mutations of the epidermal growth factor receptor (EGFR) gene are present in some patients with lung adenocarcinoma, with the implication that patients with this genotype were super responders to EGFR-tyrosine kinase inhibitors (TKIs), including gefitinib and erlotinib. In patients with a somatic EGFR mutation, frontline treatment with an EGFR inhibitor, gefitinib, results in improved response rate and superior progression-free survival. This benefit is limited to patients with EGFR mutation, as patients without the mutation have better overall response rates and progression-free survival with combination chemotherapy.

The anaplastic lymphoma kinase gene (ALK) is a member of the insulin receptor family and encodes a receptor tyrosine kinase that was originally identified in anaplastic large-cell lymphoma as a component of the fused protein NPM-ALK $[12,13]$. Subsequently, numerous other rearrangements that involve ALK have been identified, including TPM3-ALK, ATIC-ALK, TFG-ALK, CLTCALK and TPM4-ALK. In addition to anaplastic large-cell lymphoma, ALK fusion genes have also been described in half of the inflammatory myofibroblastic tumors and rare ALK-positive diffuse large B-cell lymphomas [14-17]. Recently, by screening a retroviral complementary DNA expression library generated from a NSCLC patient tumor sample, a rearrangements in the anaplastic lymphoma kinase gene (ALK) and echinoderm microtubule-associated protein-like 4 (EML4) have been identified as a result of a small inversion within the short arm of chromosome 2 between the $\mathrm{N}$-terminal half of EML4 and the intracellular kinase domain of ALK [18]. EML4-ALK rearrangement has been demonstrated to be a potent oncogenic drive and a promising therapeutic target in NSCLC. It defines a distinct molecular subset of NSCLC, in particular adenocarcinoma that can benefit by the treatment of ALK-inhibitors [19-22]. EML4-ALK gene fusions occur in $2 \%$ to $7 \%$ of lung adenocarcinomas [23-26]. ALK rearrangementpositive patients treated with a novel ALK inhibitor, crizotinib, showed an overall response rate of $57 \%$, with $72 \%$ having a PFS of 6 months or greater. The US Food and Drug Administration (FDA) has approved crizotinib for advanced-stage, ALK positive lung cancer as is also recommended by recent guidelines from professional organizations, including the American Society of Clinical Oncology (ASCO), European Society for Medical Oncology, and National Comprehensive Cancer Network (NCCN).

Despite the encouraging new target treatments have afforded benefits to patients with lung adenocarcinoma, but unfortunately the same is not true for lung $\mathrm{SqCC}[27,28]$. Notably, the vast majority of ALK gene rearrangements were observed in lung adenocarcinoma specimens. The incidence of ALK gene rearrangements in lung SqCC has not been well documented except few cases were reported [29,30]. In the present study, we carried out an immunohistochemical staining in 207 cases of consecutive lung SqCC patients with a VENTANA anti-ALK (D5F3) specific rabbit monoclonal antibody. The positive samples were confirmed with ALK Fluorescence In Situ Hybridization (FISH).

\section{Materials and methods \\ Clinical samples}

Patients diagnosed with squamous cell lung carcinoma and the tumor specimens subjected to ALK protein expression analysis in Jinling Hospital, China, between 2010 and 2014 were included in this study (Additional file 1). A total of 207 consecutive cases of squamous cell lung carcinoma were retrieved from Department of Pathology. The clinicopathologic characteristics were obtained from medical records. The tissue samples included 135 cases of surgical resection samples and 72 cases of biopsy samples. The male of female ratio of the squamous lung carcinoma patients was $181 / 26$. The median age of the patients was 63 years (range, 37-96 years). On the basis of World Health Organization Classification of Tumors (WHO), the Pathology and Genetics of Tumors of the Lung, Pleura, Thymus and Heart (2014), and International Association for the Study of Lung Cancer/American Thoracic Society/European Respiratory International Multidisciplinary Classification of Lung Adenocarcinoma [31], in 135 cases of surgical resection samples, 24 patients had stage I diseases, 31 patients had stage II diseases, 62 patients had stage III diseases, and 18 patients had stage IV diseases. The study protocol was approved by the Jinling Hospital Clinical Research Ethics Committee, China.

\section{Immunohistochemistry}

Four $\mu \mathrm{m}$-thick sections were cut from Formalin-fixed paraffin-embedded (FFPE) archive lung SqCC tissues 
blocks. Immunohistochemical staining was carried out according to the protocol provided by Ventana Medical Systems, Inc. and Roche Diagnostics International, Inc. Briefly, staining will require one serial tissue section for $H \& E$, a second serial tissue section for VENTANA antiALK (D5F3), and a third serial tissue section for the Rabbit Monoclonal Negative Control Ig antibody. The assay uses the OptiView DAB IHC Detection Kit and OptiView Amplification Kit, and is run on the BenchMark ULTRA platforms. The VENTANA ALK 2 in 1 Control Slides are used as a system-level control. Staining was graded semiquantitatively, as follows: 0 for absent or barely perceptible expression in rare cells, 1 (low) for weak to moderate multifocal expression, and 2 (high) for strong staining in most cells. Positive cases stained with the VENTANA anti-ALK (D5F3) IHC assay typically display a strong, granular cytoplasmic signal. Known staining elements should be excluded, including: light cytoplasmic stippling in alveolar macrophages, cells of neural origin (nerve and ganglion cells), glandular epithelial staining, and cells within lymphocytic infiltrate. Some background staining also may be observed within normal mucosa in NSCLC (including mucin) and in necrotic tumor areas, which also should be excluded from the clinical evaluation.

\section{Fluorescence in Situ Hybridization (FISH)}

Lung SqCC samples that positive for ALK IHC were subjected ALK FISH. Four $\mu \mathrm{m}$-thick formalin-fixed, paraffin-embedded tissue sections were used for evaluation of ALK genetic status. All cases had interphase FISH performed for ALK rearrangement with the commercial ALK dual color, break-apart rearrangement probe (GP Medical Technologies, Beijing, China). Hybridization was carried out according to the protocol provided by the manufacturer. Briefly, formalin-fixed, paraffin-embedded samples were sectioned at a thickness of $4 \mu \mathrm{m}$. The sections were deparaffinized using xylene, dehydrated by gradient ethanol, and rehydrated with deionized water. The prepared slides were washed with $2 \mathrm{x}$ SSC, treated with $0.1 \mathrm{~mol} / \mathrm{L} \mathrm{HCl}$, and digested with pepsin (P700; SigmaAldrich, St. Louis, MO). The slides and probe mixture were denatured separately. The denatured probe mixture was pipetted onto slides, and hybridization was performed in a wet box at $37^{\circ} \mathrm{C}$ overnight. After being washed, the air-dried slides were restained with 4, 6-diamindino-2phenylindole before being analyzed. One hundred individual interphase nuclei per specimen were enumerated based on localization in the corresponding H\&E-stained sections. Samples were classified as positive for ALK rearrangement when $15 \%$ or more of nuclei showed split signals (i.e., red and green signals were separated by $\geq 2$ signal diameters) or single red signals ( $3^{\prime}$ ALK) were observed. H\&E and FISH slides for all cases were reviewed by two pathologists to confirm that scoring was carried out in the tumor cell population.

\section{EML4-ALK RT-PCR}

Total RNA was extracted from the formalin-fixed, paraffin-embedded tissue with the RNeasy FFPE Kit (Qiagen, Hamburg, Germany). Reverse transcription and the detection of EML4-ALK were performed with the EML4-ALK Fusion Gene Detection Kit (AmoyDx, Xiamen, China). The primer sets used to amplify EML4-ALK variant $1,3 \mathrm{a} / \mathrm{b}, 2,5^{\prime}$, and $5 \mathrm{a} / \mathrm{b}$ are included in the kit. PCR was performed with the following parameters: denaturation at $95^{\circ} \mathrm{C}$ for $5 \mathrm{~min} ; 15$ cycles of $95^{\circ} \mathrm{C}$ for $25 \mathrm{~s}, 64^{\circ} \mathrm{C}$ for $20 \mathrm{~s}$, and $72^{\circ} \mathrm{C}$ for $20 \mathrm{~s}$; and 31 cycles of $93^{\circ} \mathrm{C}$ for $25 \mathrm{~s}, 60^{\circ} \mathrm{C}$ for $35 \mathrm{~s}$, and $72^{\circ} \mathrm{C}$ for $20 \mathrm{~s}$.

\section{Results}

\section{ALK immunohistochemistry}

All lung SqCC samples were diagnosed combining morphologic appearance and IHC staining including thyroid transcription factor-1 (TTF-1), transformation-related protein 63 (p63) and/or cytokeratin (CK5/6) (Figure 1). The intensity of staining ranges from weak, intermediate to strongly positive. Heterogeneous staining was noted from the same case. Of the 207 cases by immunohistochemistry, cytoplasmic expression of ALK was strongly (marker 2) observed in 3 cases with the VENTANA anti-ALK (D5F3), intermediately (marker 1) stained in 2 cases and weakly (marker 1) stained in 4 cases (Figure 2).

\section{ALK FISH}

All cases of SqCC samples with expression of ALK (marker 1 and 2) were confirmed by ALK FISH. A break-apart signal pattern, where one fusion signal and a single red and green signal pattern was observed in most nuclei. A few nuclei showed a predominant signal pattern of deletion of the 5 ' region (nuclei with a single red signal in addition to a fused signal). Six case of lung SqCC with weak or intermediate staining of ALK showed FISH negative, while other 3 cases of lung SqCC with strong staining of ALK showed positive for ALK FISH (Figure 3).

\section{EML4-ALK rearrangement detected with RT-PCR}

We investigated the presence of the EML4-ALK fusion variant in 30 samples of Sq CC using RT-PCR, which including 3 samples that were positive for IHC. The rearrangement-positive was confirmed in these three samples and rearrangement-negative was found in other samples.

\section{Discussion}

Immunohistochemistry for ALK protein expression has been available for many years for use in the diagnosis of 

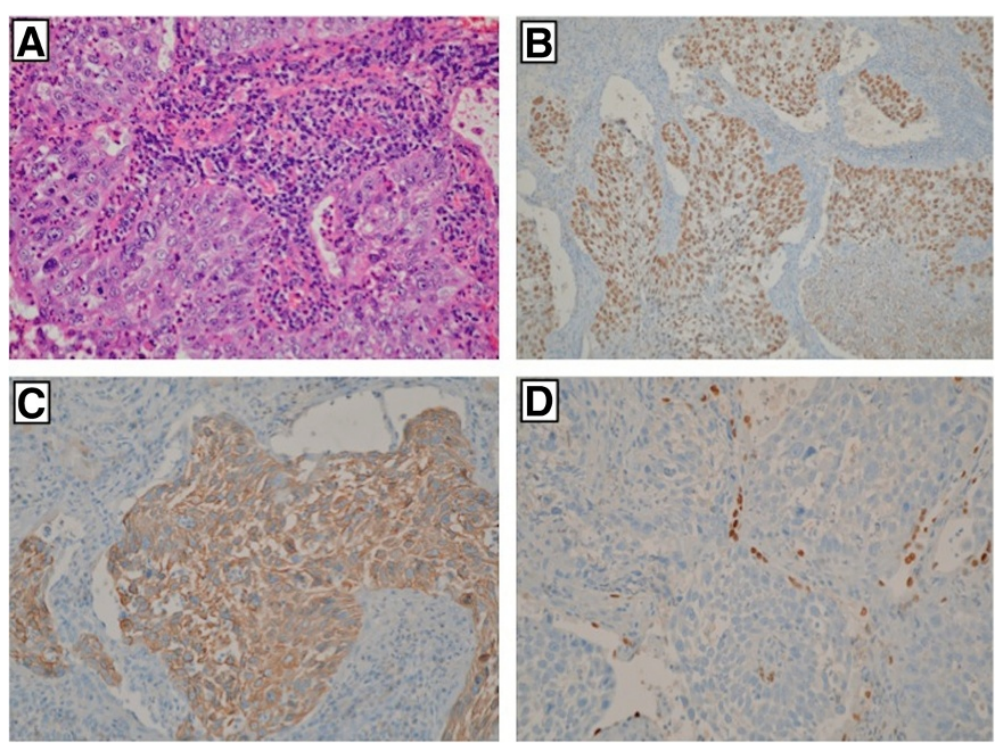

Figure 1 Lung SqCC samples were diagnosed combining morphologic appearance and IHC staining including thyroid transcription factor-1 (TTF-1), transformation-related protein 63 (p63) and/or cytokeratin (CK5/6). A: Hematoxlin and eosin staining. B: IHC staining for p63. C: IHC staining for CK5/6. D: IHC staining for TTF-1. Original magnification, $\times 400$.

anaplastic large-cell lymphoma, but the traditional antibodies for use in lymphoma are insufficiently sensitive for detection at the level at which it is expressed in ALK-rearranged lung cancers. However, several recent studies have demonstrated that several relatively new ALK clones can accurately identify ALK-rearranged lung ACA as compared with FISH $[2,8,29,32,33]$. Studies published comparing the 5A4 antibody with ALK FISH demonstrated a sensitivity and specificity of $95 \%$ to $100 \%$.
Although strong staining seems to be $100 \%$ specific for the presence of rearrangement by FISH, weak-tointermediate staining has been reported in FISHnegative tumors. In the present study, we detected 9 cases of positive expression of ALK, which including 3 strong staining, 2 intermediate staining and 4 weak staining. Three cases with strong staining were positive and other 6 cases were negative for ALK FISH. Although break-apart FISH is the standard method for diagnosis,
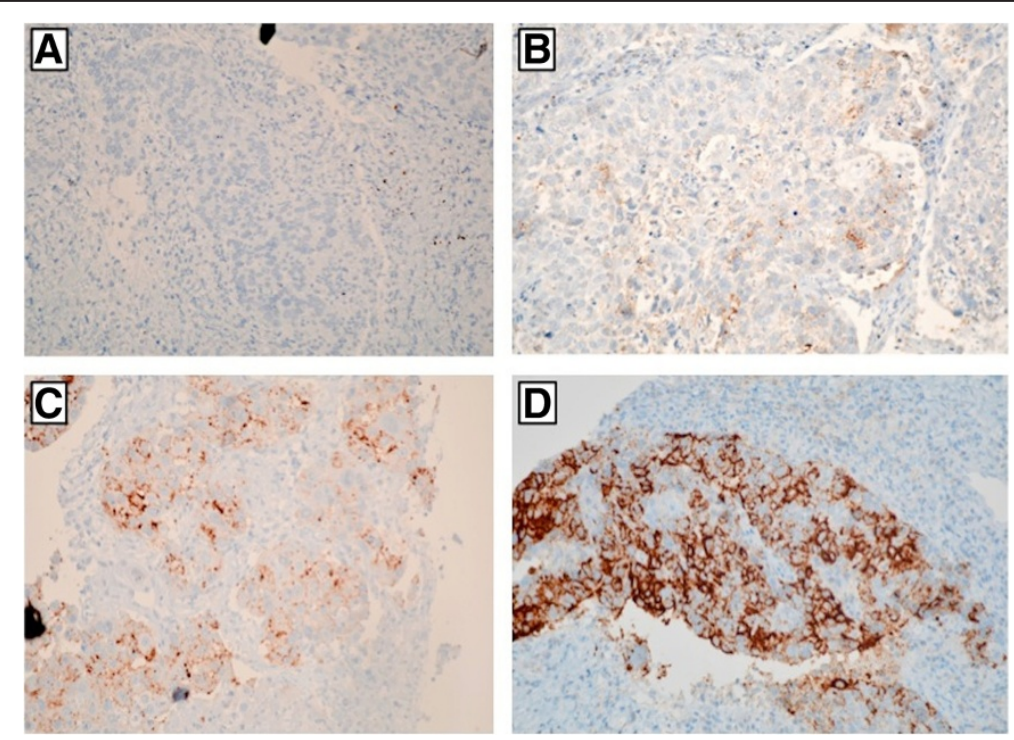

Figure 2 Representative ALK IHC images. A: Negative. B: Weak expression. C: Moderate expression. D: Strong staining. Original magnification, $\times 400$. 

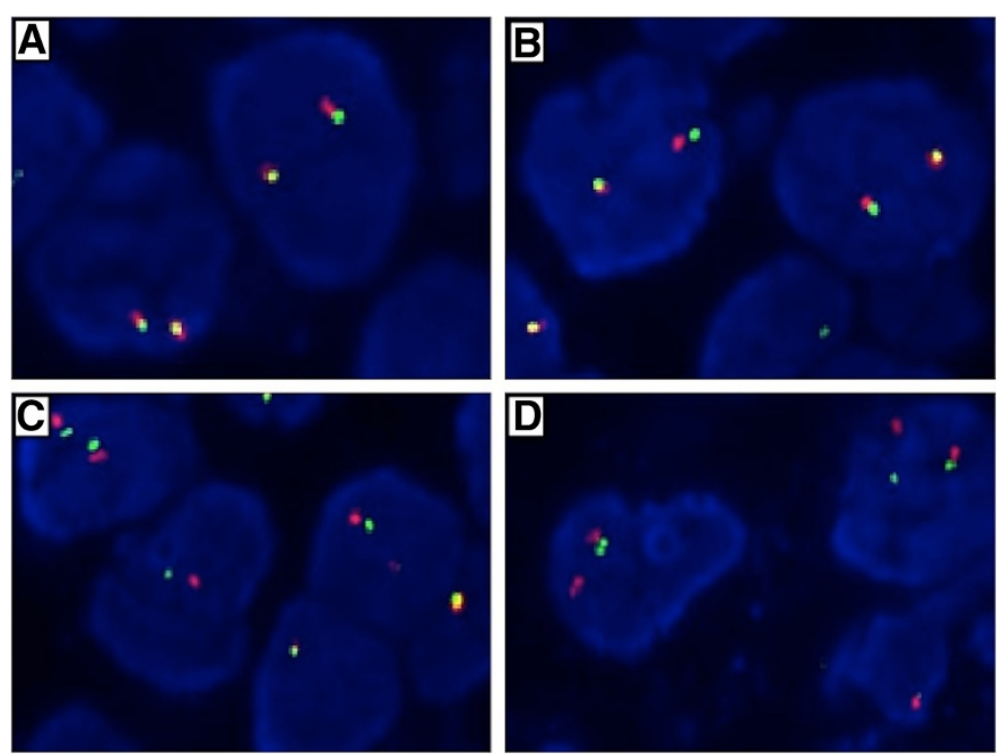

Figure 3 Dual-color, break-apart fluorescent in situ hybridization was performed to confirm the ALK expression. The centromeric (green) and telomeric (red) fland the ALK locus. Splitting of the red and green signals indicates ALK rearrangement. A: No EML4-ALK rearrangement. B, C and D: EML4-ALK rearrangements. A break-apart signal pattern, where one fusion signal and a single red and green signal pattern was observed in most nuclei (B and $\mathbf{C}$ ). A few nuclei showed a predominant signal pattern of deletion of the 5'region (D).

it is expensive, not readily available and sometimes difficult to interpret. Immunohistochemistry for ALK protein overexpression is a promising screening modality, with newer antibodies showing excellent sensitivity and specificity for ALK-rearranged lung.

The echinoderm microtubule-associated protein-like 4 anaplastic lymphoma kinase (EML4-ALK) fusion gene has been identified as a potent oncogenic driver in nonsmall-cell lung cancer, in particular adenocarcinoma. It defines a distinct molecular subset of NSCLC that can benefit by the treatment of ALK-inhibitors. ALK rearrangements have been reported to occur at frequencies that range from 0.4 to $15 \%$ in NSCLC. Some series included patient populations likely to be enriched for ALK rearrangements, however, the average frequency in unselected NSCLC populations is around 3-4\%. Though different groups investigated frequency of EML4-ALK fusion gene in NSCLC, among those NSCLC the sample number of lung SqCC was not large enough. People pay more attentions on lung adenocarcinoma than on lung SqCC. Eventually, some groups excluded SqCC from their study on EML4-ALK $[2,10,19,34]$. Can we eliminate squamous cell carcinoma of the lung from testing of EML4-ALK fusiong gene? Takigawa et al. recently raised the question [30]. They reported a 45 years old Japanese woman diagnosed as squamous cell carcinoma of lung harbored EML4-ALK gene rearrangement. Interestingly, Benepal et al. reported that an ALK rearrangement detected by FISH in a 69-year-old Caucasian gentleman diagnosed as lung squamous cell carcinoma [29]. Table 1 shows the prevalence of ALK positive SqCC all over the world [29,30,32,35].

Out results indicate that EML4-ALK fusion gene rearrangements occurred in $1.4 \%$ lung SqCC in Chinese population, which is not a rare molecular event and may have an impact on treatment choice or response to therapy. Although the frequency of these mutations is lower in lung SqCC than that in lung adenocarcinomas, their

Table 1 ALK rearrangement study reports in squamous cell lung cancer patients

\begin{tabular}{|c|c|c|c|c|c|c|c|c|}
\hline \multirow[t]{2}{*}{ No. } & \multirow[t]{2}{*}{ Authors (reference No.) } & \multirow[t]{2}{*}{ Ethnic group } & \multirow[t]{2}{*}{ Patient number } & \multicolumn{3}{|c|}{ Methods used in detection of ALK } & \multicolumn{2}{|c|}{ ALK detection } \\
\hline & & & & RT-PCR & $\mathrm{IHC}$ & $\mathrm{FISH}$ & Positive & Negative \\
\hline 1 & Wu et al. [32] & Asian & 75 & Yes & Yes & ND & $1(1.33 \%)$ & 74(98.67\%) \\
\hline 2 & Alrifai et al. [29] & Caucasian & 1 & ND & ND & Yes & 1 & 0 \\
\hline 3 & Ochi et al. [30] & Asian & 1 & ND & Yes & ND & 1 & 0 \\
\hline 4 & Calio et al. [35] & Caucasian & 40 & ND & ND & Yes & $1(2.5 \%)$ & $39(97.5 \%)$ \\
\hline
\end{tabular}

RT-PCR: reverse transcriptase-polymerase chain reaction; FISH: fluorescence in situ hybridization; IHC: immunohistochemical stain; ND: not done. 
presence may provide additional treatment options in this group. The response of SqCC patients with ALK expression to target therapy of crizotinib should be explored. A more detailed clinicopathologic study, including examination of clinical outcomes in ALK positive versus carefully matched ALK negative patients, is in progress, results of which will be reported separately.

\section{Additional file}

Additional file 1: The clinical pathological parameters of patients.

\section{Competing interests}

The authors declare that they have no competing interests.

\section{Authors' contributions}

JDW was involved in data analysis, interpretation of the results and writing of the manuscript; QS, QLS, BY, XWX, KC were involved in tissue sample collection and were involved in IHC and FISH; GML and XJZ were involved in data analysis. All authors read and approved the final manuscript.

\section{Acknowledgements}

This work was supported in part by the National Natural Science Foundation of China $(81371611,81171391,81372743)$ and the National Basic Research Priorities Program 973 Project (2014CB744504) from the Ministry of Science and Technology of China.

\section{Author details}

'Department of Pathology, Jinling Hospital, Nanjing University School of Medicine, Nanjing 210002, China. '2Department of Radiology, Jinling Hospital, Nanjing University School of Medicine, Nanjing 210002, China.

Received: 2 November 2014 Accepted: 5 December 2014 Published online: 21 December 2014

\section{References}

1. Kim C, Chapman RS, Hu W, He X, Hosgood HD, Liu LZ, Lai H, Chen W, Silverman DT, Vermeulen R, Tian L, Bassig B, Shen M, Zhang Y, Ma S, Rothman N, Lan Q: Smoky coal, tobacco smoking, and lung cancer risk in Xuanwei, China. Lung Cancer 2014, 84:31-35.

2. Sholl LM, Weremowicz S, Gray SW, Wong KK, Chirieac LR, Lindeman NI, Hornick JL: Combined use of ALK immunohistochemistry and FISH for optimal detection of ALK-rearranged lung adenocarcinomas. J Thorac Oncol 2013, 8:322-328.

3. She J, Yang P, Hong Q, Bai C: Lung cancer in China: challenges and interventions. Chest 2013, 143:1117-1126.

4. Raaschou-Nielsen O, Andersen ZJ, Beelen R, Samoli E, Stafoggia M, Weinmayr G, Hoffmann B, Fischer P, Nieuwenhuijsen MJ, Brunekreef B, Xun WW, Katsouyanni K, Dimakopoulou K, Sommar J, Forsberg B, Modig L, Oudin A, Oftedal B, Schwarze PE, Nafstad P, De Faire U, Pedersen NL, Ostenson CG, Fratiglioni L, Penell J, Korek M, Pershagen G, Eriksen KT, Sørensen M, Tjønneland A, et al: Air pollution and lung cancer incidence in 17 European cohorts: prospective analyses from the European Study of Cohorts for Air Pollution Effects (ESCAPE). Lancet Oncol 2013, 14:813-822.

5. Jemal A, Bray F, Center MM, Ferlay J, Ward E, Forman D: Global cancer statistics. CA Cancer J Clin 2011, 61:69-90.

6. Shibata T, Kokubu A, Tsuta K, Hirohashi S: Oncogenic mutation of PIK3CA in small cell lung carcinoma: a potential therapeutic target pathway for chemotherapy-resistant lung cancer. Cancer Lett 2009, 283:203-211.

7. Solomon B, Varella-Garcia M, Camidge DR: ALK gene rearrangements: a new therapeutic target in a molecularly defined subset of non-small cell lung cancer. J Thorac Oncol 2009, 4:1450-1454.

8. Lo FY, Tan YH, Cheng HC, Salgia R, Wang YC: An E3 ubiquitin ligase: c-Cbl: a new therapeutic target of lung cancer. Cancer 2011, 117:5344-5350.

9. Sunaga N, Kaira K, Imai H, Shimizu K, Nakano T, Shames DS, Girard L, Soh J, Sato M, Iwasaki Y, Ishizuka T, Gazdar AF, Minna JD, Mori M: Oncogenic
KRAS-induced epiregulin overexpression contributes to aggressive phenotype and is a promising therapeutic target in non-small-cell lung cancer. Oncogene 2013, 32:4034-4042.

10. Xia N, An J, Jiang QQ, Li M, Tan J, Hu CP: Analysis of EGFR, EML4-ALK, KRAS, and c-MET mutations in Chinese lung adenocarcinoma patients. Exp Lung Res 2013, 39:328-335.

11. Douillard JY, Pirker R, O'Byrne KJ, Kerr KM, Storkel S, von Heydebreck A, Grote HJ, Celik I, Shepherd FA: Relationship between EGFR expression, EGFR mutation status, and the efficacy of chemotherapy plus cetuximab in FLEX study patients with advanced non-small-cell lung cancer. J Thorac Oncol 2014, 9:717-724.

12. Waggott W, Lo YM, Bastard C, Gatter KC, Leroux D, Mason DY, Boultwood J, Wainscoat JS: Detection of NPM-ALK DNA rearrangement in CD30 positive anaplastic large cell lymphoma. Br J Haematol 1995, 89:905-907.

13. Pileri SA, Pulford K, Mori S, Mason DY, Sabattini E, Roncador G, Piccioli M, Ceccarelli C, Piccaluga PP, Santini D, Leone O, Stein H, Falini B: Frequent expression of the NPM-ALK chimeric fusion protein in anaplastic large-cell lymphoma, lympho-histiocytic type. Am J Pathol 1997, 150:1207-1211.

14. Lawrence B, Perez-Atayde A, Hibbard MK, Rubin BP, Dal Cin P, Pinkus JL, Pinkus GS, Xiao S, Yi ES, Fletcher CD, Fletcher JA: TPM3-ALK and TPM4-ALK oncogenes in inflammatory myofibroblastic tumors. Am J Pathol 2000, 157:377-384.

15. Gesk S, Gascoyne RD, Schnitzer B, Bakshi N, Janssen D, Klapper W, Martin-Subero II, Parwaresch R, Siebert R: ALK-positive diffuse large B-cell lymphoma with ALK-Clathrin fusion belongs to the spectrum of pediatric lymphomas. Leukemia 2005, 19:1839-1840.

16. Marino-Enriquez A, Wang WL, Roy A, Lopez-Terrada D, Lazar AJ, Fletcher CD, Coffin CM, Hornick JL: Epithelioid inflammatory myofibroblastic sarcoma: An aggressive intra-abdominal variant of inflammatory myofibroblastic tumor with nuclear membrane or perinuclear ALK. Am J Surg Pathol 2011, 35:135-144

17. Yoshida A, Shibata T, Tsuta K, Watanabe S, Tsuda H: Inflammatory myofibroblastic tumour of the lung with a novel PPFIBP1-ALK fusion variant. Histopathology 2013, 63:881-883.

18. Soda M, Choi YL, Enomoto M, Takada S, Yamashita Y, Ishikawa S, Fujiwara S, Watanabe H, Kurashina K, Hatanaka H, Bando M, Ohno S, Ishikawa Y, Aburatani H, Niki T, Sohara Y, Sugiyama Y, Mano H: Identification of the transforming EML4-ALK fusion gene in non-small-cell lung cancer. Nature 2007, 448:561-566.

19. Chiari R, Duranti S, Ludovini V, Bellezza G, Pireddu A, Minotti V, Bennati C, Crino L: Long-term response to gefitinib and crizotinib in lung adenocarcinoma harboring both epidermal growth factor receptor mutation and EML4-ALK fusion gene. J Clin Oncol 2014, 32:e30-e32.

20. Pop O, Pirvu A, Toffart AC, Moro-Sibilot D: Disease flare after treatment discontinuation in a patient with EML4-ALK lung cancer and acquired resistance to crizotinib. J Thorac Oncol 2012, 7:e1-e2.

21. Katayama R, Khan TM, Benes C, Lifshits E, Ebi H, Rivera VM, Shakespeare WC, lafrate AJ, Engelman JA, Shaw AT: Therapeutic strategies to overcome crizotinib resistance in non-small cell lung cancers harboring the fusion oncogene EML4-ALK. Proc Natl Acad Sci U S A 2011, 108:7535-7540.

22. Antoniu SA: Crizotinib for EML4-ALK positive lung adenocarcinoma: a hope for the advanced disease? Evaluation of Kwak EL, Bang YJ, Camidge DR, et al. Anaplastic lymphoma kinase inhibition in non-small-cell lung cancer. N Engl J Med 2010;363(18):1693-703. Expert Opin Ther Targets 2011, 15:351-353.

23. Li T, Maus MK, Desai SJ, Beckett LA, Stephens C, Huang E, Hsiang J, Zeger G, Danenberg KD, Astrow SH, Gandara DR: Large-scale screening and molecular characterization of EML4-ALK fusion variants in archival non-small-cell lung cancer tumor specimens using quantitative reverse transcription polymerase chain reaction assays. J Thorac Oncol 2014, 9:18-25.

24. Fukui T, Yatabe Y, Kobayashi Y, Tomizawa K, Ito S, Hatooka S, Matsuo K, Mitsudomi T: Clinicoradiologic characteristics of patients with lung adenocarcinoma harboring EML4-ALK fusion oncogene. Lung Cancer 2012, 77:319-325.

25. Wu SG, Kuo YW, Chang YL, Shih JY, Chen YH, Tsai MF, Yu CJ, Yang CH, Yang PC: EML4-ALK translocation predicts better outcome in lung adenocarcinoma patients with wild-type EGFR. J Thorac Oncol 2012, 7:98-104.

26. Jokoji R, Yamasaki T, Minami S, Komuta K, Sakamaki Y, Takeuchi K, Tsujimoto $\mathrm{M}$ : Combination of morphological feature analysis and immunohistochemistry is useful for screening of EML4-ALK-positive lung adenocarcinoma. J Clin Pathol 2010, 63:1066-1070. 
27. Yue $D$, Li H, Che J, Zhang Y, Tseng HH, Jin JQ, Luh TM, GirouX-Leprieur E, Mo M, Zheng Q, Shi H, Zhang H, Hao X, Wang C, Jablons DM, He B: Hedgehog/Gli promotes epithelial-mesenchymal transition in lung squamous cell carcinomas. J Exp Clin Cancer Res 2014, 33:34.

28. Abbruzzese C, Mattarocci S, Pizzuti L, Mileo AM, Visca P, Antoniani B, Alessandrini G, Facciolo F, Amato R, D'Antona L, Rinaldi M, Felsani A, Perrotti N, Paggi MG: Determination of SGK1 mRNA in non-small cell lung cancer samples underlines high expression in squamous cell carcinomas. J Exp Clin Cancer Res 2012, 31:4.

29. Alrifai D, Popat S, Ahmed M, Gonzalez D, Nicholson AG, Parcq J, Benepal T: A rare case of squamous cell carcinoma of the lung harbouring ALK and BRAF activating mutations. Lung Cancer 2013, 80:339-340.

30. Ochi N, Yamane H, Yamagishi T, Takigawa N, Monobe Y: Can we eliminate squamous cell carcinoma of the lung from testing of EML4-ALK fusion gene? Lung Cancer 2013, 79:94-95.

31. Travis WD, Brambilla E, Noguchi M, Nicholson AG, Geisinger KR, Yatabe $Y$, Beer DG, Powell CA, Riely GJ, Van Schil PE, Garg K, Austin JH, Asamura H, Rusch WW, Hirsch FR, Scagliotti G, Mitsudomi T, Huber RM, Ishikawa Y, Jett J, Sanchez-Cespedes M, Sculier JP, Takahashi T, Tsuboi M, Vansteenkiste J, Wistuba I, Yang PC, Aberle D, Brambilla C, Flieder D, et al: International association for the study of lung cancer/american thoracic society/european respiratory society international multidisciplinary classification of lung adenocarcinoma. J Thorac Oncol 2011, 6:244-285.

32. Wu YC, Chang IC, Wang CL, Chen TD, Chen YT, Liu HP, Chu Y, Chiu YT, Wu TH, Chou LH, Chen YR, Huang SF: Comparison of IHC, FISH and RT-PCR methods for detection of ALK rearrangements in 312 non-small cell lung cancer patients in Taiwan. PLoS One 2013, 8:e70839.

33. Selinger $\mathrm{Cl}$, Rogers TM, Russell PA, O'Toole S, Yip P, Wright GM, Wainer Z Horvath LG, Boyer M, McCaughan B, Kohonen-Corish MR, Fox S, Cooper WA, Solomon B: Testing for ALK rearrangement in lung adenocarcinoma: a multicenter comparison of immunohistochemistry and fluorescent in situ hybridization. Mod Pathol 2013, 26:1545-1553.

34. To KF, Tong JH, Yeung KS, Lung RW, Law PP, Chau SL, Kang W, Tong CY, Chow C, Chan AW, Leung LK, Mok TS: Detection of ALK rearrangement by immunohistochemistry in lung adenocarcinoma and the identification of a novel EML4-ALK variant. J Thorac Oncol 2013, 8:883-891.

35. Dragnev KH, Gehr G, Memoli VA, Tafe L: ALK-rearranged adenosquamous lung cancer presenting as squamous cell carcinoma: a potential challenge to histologic type triaging of NSCLC biopsies for molecular studies. Clin Lung Cancer 2014, 15:e37-e40.

\section{Submit your next manuscript to BioMed Central and take full advantage of:}

- Convenient online submission

- Thorough peer review

- No space constraints or color figure charges

- Immediate publication on acceptance

- Inclusion in PubMed, CAS, Scopus and Google Scholar

- Research which is freely available for redistribution 